\title{
Delayed Modified Atmosphere Packaging of Fresh-cut Romaine Lettuce: Effects on Quality Maintenance and Shelf-life
}

\author{
Ji Gang Kim1, Yaguang Luo², Robert A. Saftner, and Kenneth C. Gross \\ Produce Quality and Safety Laboratory, Beltsville Agricultural Research Center, Agricultural Research \\ Service, U.S. Department of Agriculture, Beltsville, MD 20705
}

\begin{abstract}
ADDITIONAL INDEX WORDS. $\mathrm{CO}_{2}$ injury, electrolyte leakage, oxygen transmission rate, postharvest technology
ABSTRACT. Fresh-cut tissues are subjected to severe injury during preparation that leads to increased respiratory activity and quality deterioration. Modified atmosphere packaging (MAP) has been used to maintain quality of fresh-cut produce, but $\mathrm{O}_{2}$ depletion and excessive $\mathrm{CO}_{2}$ accumulation can be injurious. This study was conducted to evaluate the effect of delayed packaging and MAP using two different oxygen transmission rate (OTR) films on quality maintenance and shelf stability of fresh-cut romaine lettuce (Lactuca sativa L.). Romaine lettuce leaves were cut, washed, dried, and placed for $0,4,8$, and 12 hours at $5^{\circ} \mathrm{C}$ in ambient air before packaging. Fresh-cut samples were placed into packages prepared from films having OTRs of 8.0 and $16.6 \mathrm{pmol} \cdot \mathrm{s}^{-1} \cdot \mathrm{m}^{-2} \cdot \mathrm{Pa}^{-1}$, flushed with $\mathrm{N}_{2}$ to reach an initial headspace $\mathrm{O}_{2}$ level of $1.5 \mathrm{kPa} \mathrm{O}_{2}$, and stored at $5^{\circ} \mathrm{C}$ for up to 14 days. Delayed packaging affected gas composition, fermentative volatile production, off-odor development, color, $\mathrm{CO}_{2}$ injury, and tissue electrolyte leakage. With increasing delay before packaging, fermentative volatile production, off-odor development, and $\mathrm{CO}_{2}$ injury progressively decreased and discoloration increased. The modified atmospheres obtained with 16.6 OTR film increased discoloration when present, and generally had less off-odor development and $\mathrm{CO}_{2}$ injury compared to MAP with 8.0 OTR film. Delayed packaging affected overall quality of fresh-cut romaine lettuce packaged with both films. A 12-hour delayed packaging into packages prepared from 8.0 OTR film maintained quality by inhibiting $\mathrm{CO}_{2}$ injury, off-odor development, and tissue electrolyte leakage. However, an 8-hour delayed packaging into packages prepared from 16.6 OTR film was better at maintaining the quality of fresh-cut romaine lettuce at $5^{\circ} \mathrm{C}$ for 14 days. The results indicated that delayed packaging could be an alternative method to optimize or balance package $\mathrm{O}_{2}$ during suboptimal OTR film packaging conditions.
\end{abstract}

Packaged fresh-cut vegetables are becoming more and more popular because they are convenient and ready-to-eat. The freshcut produce industry has been on a double-digit growth rate in response to an increased demand by consumers. However, fresh-cut produce has limited shelf stability due to rapid quality deterioration (Huxsoll et al., 1989; Jacxsens et al., 2002). The major technical issues associated with packaged fresh-cut romaine lettuce are discoloration and decay. Modified atmosphere packaging (MAP) technology has been successfully used to control both discoloration and decay. It is essential to maintain an optimum balance of $\mathrm{O}_{2}$ and $\mathrm{CO}_{2}$ in the packages to minimize discoloration and decay. The balanced atmospheres are afforded by the selection of suitable film oxygen transmission rate (OTR), respiring surface area, product weight, and respiration rate (Lakakul et al., 1999). Packages are often flushed with $\mathrm{N}_{2}$ to reach a desired initial $\mathrm{O}_{2}$ level to increase the $\mathrm{O}_{2}$ equilibration rate and to control browning immediately after processing. However, this practice faces several challenges due to the large variations in respiration rate from different varieties, large seasonal variation, and postharvest storage duration prior to processing. In particular, the large variation in respiration rate often results in $\mathrm{O}_{2}$ being either too high or too low in the package, resulting in the development of tissue discoloration when $\mathrm{O}_{2}$ is higher than optimal or tissue

Received for publication 4 Mar. 2004. Accepted for publication 21 May 2004. The authors wish to thank Willard Douglas for adjusting an automatic system to rapidly measure respiration and ethylene production rates of fresh-cut lettuce. Use of a company name or product by the USDA does not imply approval or recommendation of the product to the exclusion of others that also may be suitable.

${ }^{1}$ National Horticultural Research Institute, Rural Development Administration, Suwon 440-706, Republic of Korea.

'Corresponding author: e-mail Luoy@ba.ars.usda.gov injury when $\mathrm{CO}_{2}$ concentrations exceed $5 \mathrm{kPa}$ (Smyth et al., 1998). Theoretically, the best way to optimize package atmosphere is to select films that match the OTR of the film to the respiration rate of the produce. However, in practice, changing films in a commercial setting quickly enough to correct for changing respiration rates of the produce being packaged is not feasible. Therefore, alternative methods to optimize or balance package $\mathrm{O}_{2}$ during suboptimal OTR film packaging are needed. One method to potentially affect package atmosphere is to delay packaging, thereby avoiding the transiently high respiration rates that occur immediately after processing. It is generally believed that freshcut lettuce needs to be packaged immediately after processing to avoid discoloration. However, due to logistical issues, packaging delays up to $12 \mathrm{~h}$ or more frequently occur in the industry. The extended exposure of processed lettuce to ambient air during delayed packaging on the postharvest physiology of lettuce, the changes in package atmospheres, and product quality have not been studied. The objective of this study was to investigate the effect of delayed packaging and passively induced MAP using two films of differing OTR on quality maintenance and shelf stability of packaged fresh-cut romaine lettuce.

\section{Materials and Methods}

Plants, Processing,and PaCKaging. Romaine lettuce was obtained from a local wholesale market and processed immediately. Fresh romaine lettuce leaves were cut into $\approx 2.5 \times 2.5$-cm slices, washed using an industrial size washer (model MPW 800; Meyer Machine Co., San Anotonio, Tex.) in $100 \mathrm{mg} \cdot \mathrm{mL}^{-1}$ chlorine solution $(\mathrm{NaOCl})$ adjusted to $\mathrm{pH} 6.5$ with $\mathrm{HCl}$ for $1 \mathrm{~min}$, and centrifuged using a salad centrifugal dryer (model T-304; Meyer Machine 
Co. $)$ at $650 \mathrm{rpm}\left(\approx 111 g_{\mathrm{n}}\right)$ for $2.5 \mathrm{~min}$ to remove excess water. Fresh-cut romaine lettuce samples (170 g each) were stored in air at $5{ }^{\circ} \mathrm{C}$ for $0,4,8$, and $12 \mathrm{~h}$. The samples were transferred into packages $(19 \times 19 \mathrm{~cm})$ prepared from two films differing in OTR (see below), and the packages were flushed with $1.5 \mathrm{kPa}$ $\mathrm{O}_{2}$, sealed, and stored at $5^{\circ} \mathrm{C}$ for $14 \mathrm{~d}$.

Film OTR ANALYSES. The OTRs of the two films used to prepare the packages were 8.0 and $16.6 \mathrm{pmol} \cdot \mathrm{s}^{-1} \cdot \mathrm{m}^{-2} \cdot \mathrm{Pa}^{-1}$, as determined by the film manufacturer (Packaging Concept, Salinas, Calif.) at $23{ }^{\circ} \mathrm{C}$ using a MOCON apparatus to measure the steady state rate of dry $\mathrm{O}_{2}$ gas transmission through plastic films, i.e., according to ASTM International procedure D 3985-81 (ASTM International, 1986). At $5{ }^{\circ} \mathrm{C}$ in air, the film OTRs were 4.6 and $8.5 \mathrm{pmol} \cdot \mathrm{s}^{-1} \cdot \mathrm{m}^{-2} \cdot \mathrm{Pa}^{-1}(8.0$ and $16.6 \mathrm{OTR}$ films), as determined following an exponential decay method for determining OTRs through plastic films in a static cell (Moyls et al., 1992) with slight modification. The oxygen concentration in a static cell initially flushed with $\mathrm{N}_{2}$ gas and stored at $5{ }^{\circ} \mathrm{C}$ in moist $[\approx 90 \%$ relative humidity $(\mathrm{RH})$ ] air was measured continuously using a noninvasive $\mathrm{O}_{2}$ analyzer (model 101; OxySense Inc., Las Vegas, Nev.). The slopes obtained from linear regressions of the test cell data (average of three samples) predicted the film OTRs. Gas transmission rates through plastic films calculated from test data using the exponential decay method compare favorably with values obtained by a MOCON apparatus (Moyls et al., 1992).

Carbon dioxide and ETHYlene Production rates aNd RESPIRATION-ASSOCIATED GAS ANALYSES. Fresh-cut romaine lettuce samples (200 g each) were placed in sealed containers at $5{ }^{\circ} \mathrm{C}$ with humidified 1.5 and $21 \mathrm{kPa} \mathrm{O}_{2}$ (balance $\mathrm{N}_{2}$ ) at a flow rate of $20 \mathrm{~mL} \cdot \mathrm{min}^{-1}$. The $\mathrm{CO}_{2}$ content of the outlet streams from sample containers was monitored every hour for the first $3 \mathrm{~d}$ and every 6 $\mathrm{h}$ for the next $11 \mathrm{~d}$ using a gas chromatograph [GC (HP 5890a; Hewlett Packard Co., Rockville, Md.)] fitted with a Hayesep Q column $(2.4 \mathrm{~m} \times 3 \mathrm{~mm})$ and a thermal conductivity detector. The ethylene content of the outlet streams was also measured using a GC (HP 5890a) equipped with a GS-Q column $[3.0 \mathrm{~m} \times 0.53 \mathrm{~mm}$ (J\&W Scientific, Folsom, Calif.)] and a flame ionization detector. The partial pressure of $\mathrm{O}_{2}$ and $\mathrm{CO}_{2}$ within packages of fresh-cut romaine lettuce was measured using a gas analyzer system (Combi Check 9800-1; PBI Dansensor Co., Ringsted, Denmark).

VolATILE ANALYSES. Ethanol and acetaldehyde concentrations in the headspace of packages containing fresh-cut romaine lettuce were determined using a gas chromatographic procedure. Gas samples $(250 \mu \mathrm{L})$ were collected from packages of freshcut romaine lettuce using a gas-tight syringe and injected into a glass-lined splitless injection port of a gas chromatograph (model 6890N; Agilent Technologies, Rockville, Md.) equipped with a flame ionization detector. Volatiles were separated using a capillary column [30 $\mathrm{m} \times 0.32 \mathrm{~mm}$ i.d., $1.0 \mu \mathrm{m}$ coating thickness (DBWAX; J\&W Scientific)]. The carrier gas was ultra purified helium (6.0 research) at a flow velocity of $36 \mathrm{~cm} \cdot \mathrm{s}^{-1}$. The temperature program was isothermal for $5 \mathrm{~min}$ at $40{ }^{\circ} \mathrm{C}$ and then raised at $15^{\circ} \mathrm{C} / \mathrm{min}$ to $160^{\circ} \mathrm{C}$, and held for $3 \mathrm{~min}$. Injector and detector temperatures were 200 and $250{ }^{\circ} \mathrm{C}$, respectively. Quantification was done using a relative calibration procedure using known concentrations of standards.

Electrolyte leakage. For electrical conductivity measurement, fresh-cut romaine lettuce samples $(50 \mathrm{~g})$ were immersed in 500-mL aliquots of distilled water at $5^{\circ} \mathrm{C}$ for $30 \mathrm{~min}$ (Jiang et al., 2001). Conductivity was measured using a conductivity meter (model 135A; Orion Research, Beverly City, Mass.) by inserting a probe into the sample solutions. Total sample electrolyte levels were determined on the same sample after freeze $\left(-20{ }^{\circ} \mathrm{C}\right.$ for 24 h)/thawing, and electrolyte leakage is expressed as percent total electrolytes (Hong and Gross, 1998).

QuALITYATTRIBUTES. Sensory quality was evaluated by a panel of three trained personnel. The samples were coded with three-digit numbers to mask the treatment identity in an effort to minimize the test subjectivity and to ensure test accuracy. Off-odor was evaluated immediately after opening the packages and scored on a five-point scale where $0=$ none; 1 = slight; $2=$ moderate; 3 = strong; and 4 = severe (Lopez-Galvez et al., 1997): a score of 3 was considered non-acceptable. Discoloration was evaluated using a five-point scoring system but pieces with discoloration were sorted into groups based on the degree of discoloration where 0 = none; 1 = beginning of discoloration as oval pinkish lesions at the edge of the midrib; $2=$ moderate browning on both sides of midrib; 3 = strong browning along the midrib; and $4=$ severe browning along the midrib. High $\mathrm{CO}_{2}$ or low $\mathrm{O}_{2}$ injury were also scored on a five-point scale based on the degree of brown staining of the fresh-cut lettuce where $0=$ none; $1=$ beginning of injury; $2=<1 / 4$ surface area injured; $3=$ between $1 / 4$ to $1 / 2$ surface area injured; and $4=>1 / 2$ surface area injured. For both discoloration and $\mathrm{CO}_{2}$ injury, results are expressed as an index score calculated by taking the sum of each score multiplied by the corresponding number of pieces in three replicate $170-\mathrm{g}$ samples having that score, dividing by the total number of lettuce pieces evaluated, and then multiplying by 100 (Lopez-Galvez et al., 1996a). Overall quality was evaluated after 14 d storage. Qual-

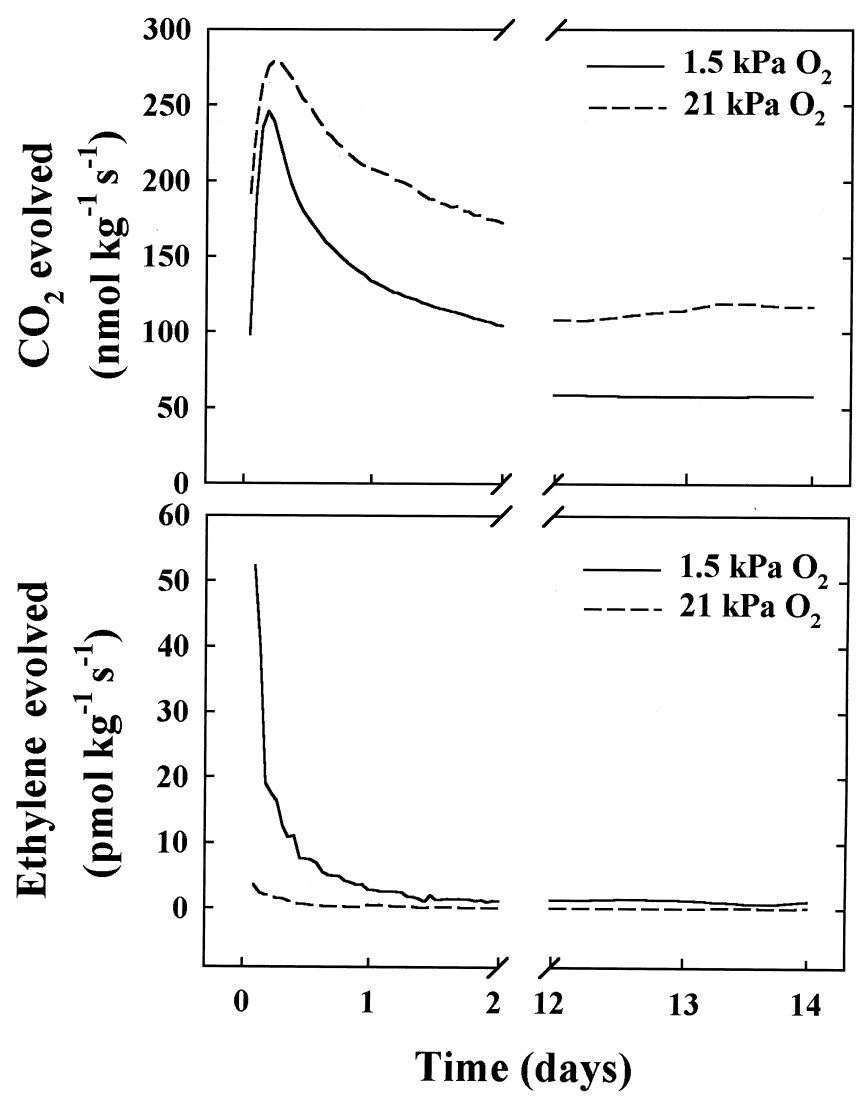

Fig. 1. Effect of 1.5 and $21 \mathrm{kPa} \mathrm{O}_{2}$ on $\mathrm{CO}_{2}$ and ethylene production rates in fresh-cut romaine lettuce stored at $5^{\circ} \mathrm{C}$ for $14 \mathrm{~d}$. Each line is the mean of three replications measured at $1-\mathrm{h}$ increments during the first $3 \mathrm{~d}$ of storage and at 6-h increments thereafter. 
ity was assessed with a nine-point hedonic scale where $9=$ like extremely; 7 = like moderately; $5=$ neither like nor dislike; $3=$ dislike moderately; and 1 = dislike extremely (Meilgaard et al., 1991): a score of 6 was considered the limit of salability (Loaiza and Cantwell, 1997; Lopez-Galvez et al., 1997). All experiments were repeated at least once.

EXPERIMENTAL DESIGN AND STATISTICAL ANALYSES. The experiment was conducted utilizing a completely randomized design. A preliminary experiment was run prior to the experiment reported here. Product quality and package atmospheres were measured at $1,2,6,10$, and $14 \mathrm{~d}$ during storage with three replications. All quality evaluations were performed in a temperature controlled room at $5{ }^{\circ} \mathrm{C}$ to minimize the effect of temperature variation during testing. Data were analyzed as a three-factor linear model using the PROC MIXED (SAS Institute, 1999) with storage time, film OTR and packaging delay as the factors. Any treatments where all the values were zero or had the same value (no variability) were omitted from the analysis. When effect(s) were statistically significant, mean comparisons were done with Sidak adjusted $P$ values so that the experiment-wise error $(\alpha)$ was $\leq 0.05$. Unless stated otherwise, only results significant at $P \leq 0.05$ are discussed.

\section{Results and Discussion}

CARBON DIOXIDE AND ETHYLENE PRODUCTION RATES. Respiration rates, measured as evolved $\mathrm{CO}_{2}$, increased rapidly upon processing, peaked at $\approx 4 \mathrm{~h}$, declined sharply during the next day, and then decreased gradually before stabilizing near the end of storage (Fig. 1). The decrease in respiration rate has been attributed to wound metabolism and/or a depletion of storage reserves (Brecht, 1995; Smyth et al., 1998). Lettuce from both 1.5 and $21 \mathrm{kPa} \mathrm{O}_{2}$ treatment had similar respiratory patterns, though the overall respiration rate in $21 \mathrm{kPa} \mathrm{O}$ was 1.2 to 2.0 times higher than that in $1.5 \mathrm{kPa} \mathrm{O}$ during storage.

Ethylene production rates, measured as evolved ethylene, decreased during the first $24 \mathrm{~h}$ after processing, and then stabilized at a low level (Fig. 1). Since wound ethylene production generally occurs within minutes and peaks within a few hours after wounding (Abeles et al., 1992), a peak in ethylene production shortly after processing may have gone undetected. Ethylene production rates were $>8$ times higher in 1.5 than in $21 \mathrm{kPa} \mathrm{O}_{2}$ during storage. While low $\mathrm{O}_{2}$ concentrations are known to stimulate ethylene production in certain plant tissues (Jackson et al., 1985) and to inhibit microbial oxidation of ethylene (Cornforth, 1975), the mechanism by which low $\mathrm{O}_{2}$ concentrations increased ethylene evolution in freshcut lettuce is not known.

Package atmospheres. The $\mathrm{O}_{2}$ partial pressure in packages prepared with 8.0 OTR film decreased rapidly (Fig. 2). The impact of delayed packaging on $\mathrm{O}_{2}$ partial pressure was minimal since atmospheric $\mathrm{O}_{2}$ decreased to $0.2 \mathrm{kPa}$ or lower in packages from all treatments within $1 \mathrm{~d}$ after packaging. Smyth et al. (1998) have previously reported that the $\mathrm{O}_{2}$ partial pressure within packaged salads was often $<0.5 \mathrm{kPa}$. While delayed packaging treatments had no significant effect on atmospheric $\mathrm{O}_{2}$, packages prepared with 16.6 OTR film had a higher $\mathrm{O}_{2}$ partial pressure than those prepared from 8.0 OTR film.

In packages prepared from 8.0 OTR film, atmospheric $\mathrm{CO}_{2}$ concentration increased throughout storage and was $>10 \mathrm{kPa}$ by day 6 (Fig. 3). Delayed packaging treatments affected the rate of $\mathrm{CO}_{2}$ accumulation $(P<0.0001)$. In general, the $\mathrm{CO}_{2}$ partial pressure was inversely related to the delay period before packaging. In packages prepared from 16.6 OTR film, $\mathrm{CO}_{2}$ increased and appeared to peak at day 6 . Among corresponding delayed packaging treatments, less $\mathrm{CO}_{2}$ accumulated in packages prepared from 16.6 OTR film than from 8.0 OTR film $(P<0.0001)$. While

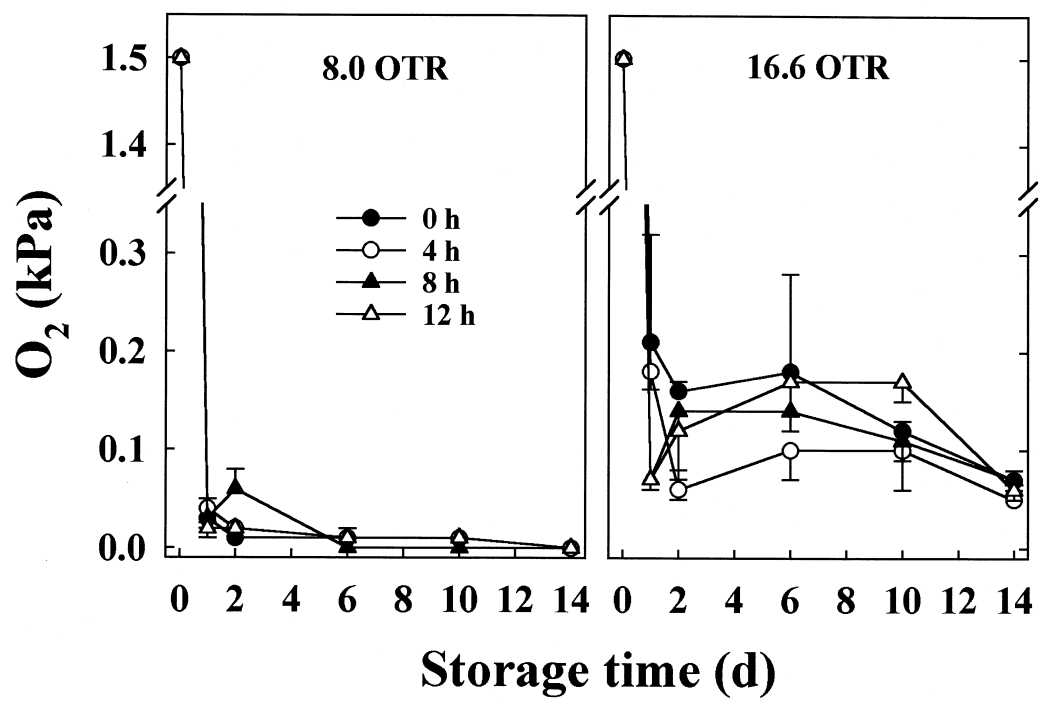

Fig. 2. Effect of delayed packaging treatments and packaging film oxygen transmission rate (OTR) on $\mathrm{O}_{2}$ partial pressure within packages of fresh-cut romaine lettuce packaged with 1.5 $\mathrm{kPa} \mathrm{O}_{2}$ and stored at $5^{\circ} \mathrm{C}$ for up to $14 \mathrm{~d}$. The delay period between fresh-cut processing and packaging lettuce samples using 8.0 or $16.6 \mathrm{pmol} \cdot \mathrm{s}^{-1} \cdot \mathrm{m}^{-2} \cdot \mathrm{Pa}^{-1}$ OTR films was 0,4 , 8 , or $12 \mathrm{~h}$. Each symbol is the mean of three replicate measurements; vertical lines represent SE. SE bars were not shown when masked by the symbol.

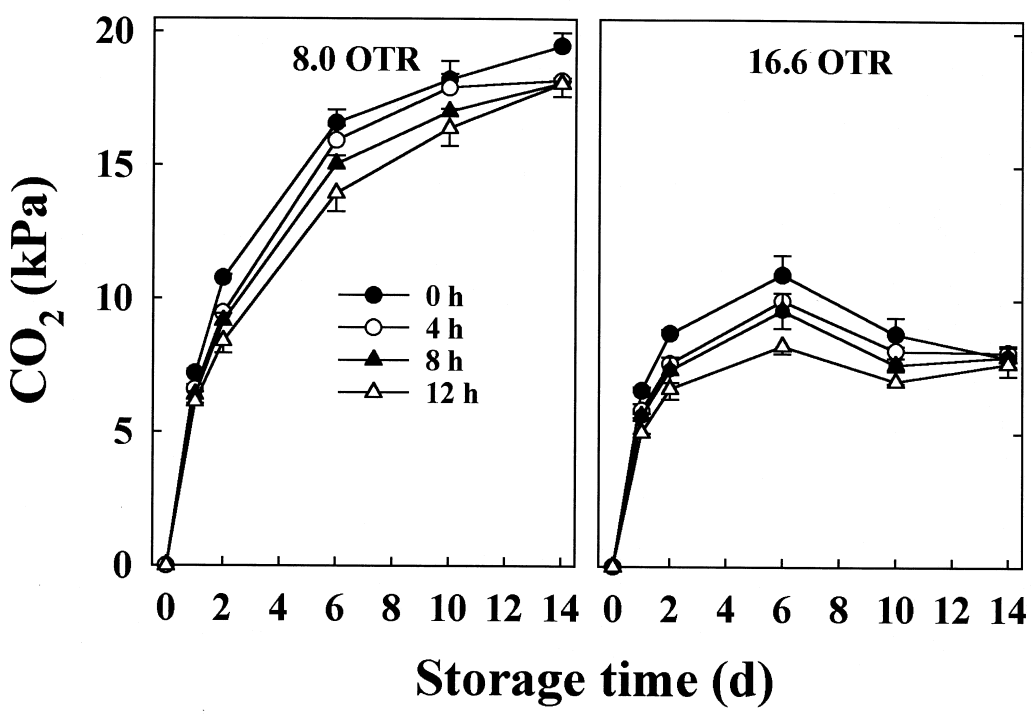

Fig. 3. Effect of delayed packaging treatments and packaging film oxygen transmission rate (OTR) on $\mathrm{CO}_{2}$ partial pressure within packages of fresh-cut romaine lettuce packaged with $1.5 \mathrm{kPa} \mathrm{O}_{2}$ and stored at $5^{\circ} \mathrm{C}$ for up to $14 \mathrm{~d}$. The delay period between fresh-cut processing and packaging lettuce samples using 8.0 or $16.6 \mathrm{pmol} \cdot \mathrm{s}^{-1} \cdot \mathrm{m}^{-2} \cdot \mathrm{Pa}^{-1}$ OTR films was $0,4,8$, or $12 \mathrm{~h}$. Each symbol is the mean of three replicate measurements; vertical lines represent SE. SE bars were not shown when masked by the symbol. 
$\mathrm{CO}_{2}$ partial pressure within packages prepared from 16.6 OTR film was $<10 \mathrm{kPa}$ throughout storage, an inverse relationship between $\mathrm{CO}_{2}$ partial pressure and the delay period before packaging was still evident at least up to day 10.

EleCtrolyte leakage. Delaying packaging periods of 8 and $12 \mathrm{~h}$ decreased electrolyte leakage (Fig. 4). For all delayed packaging treatments, electrolyte leakage, which was relatively high immediately after processing, decreased rapidly during the first $2 \mathrm{~d}$, then either decreased gradually or remained relatively stable, depending upon treatment, between days 2 and 10 before increasing during the last $4 \mathrm{~d}$ of storage. This response pattern to processing is similar to our previous findings with fresh-cut cilantro (Coriandrum sativum L.) (Luo et al., 2004) and salad savoy (Brassica oleracea $\mathrm{L}$. var. acephala $\times$ var. capitata) (Kim et al., 2004). The 12-h delayed packaging treatment transiently inhibited electrolyte leakage compared to the other treatments. Delayed packaging affected the changes in lettuce tissue electrolyte leakage packaged with both films $(P<0.0001)$. As the delay period before packaging increased, electrolyte leakage generally decreased though not always significantly. The 12-h delayed packaging treatment had the lowest electrolyte leakage through 6 and $10 \mathrm{~d}$ storage in 16.6 and 8.0 OTR film packages, respectively. Electrolyte leakage is generally considered as an indirect measure of plant cell membrane damage (Hong et al., 2000), and/or postharvest processing injury, and has been used to predict vigor, deterioration, damage of seeds, and chilling injury of fruits and vegetables (Jiang et al., 2001). Loss of membrane integrity results in an increase in ion leakage (Jiang et al., 2001). The exact mechanism of the changes in tissue electrolyte leakage is unknown. Hong and Gross (1998) reported that a rapid increase in electrolyte leakage for sliced tomato (Lycopersicon esculentum Mill.) might have been due to a change in membrane fluidity caused by cutting-induced oxidative stress. Luo et al. (2004) has suggested that the change in electrolyte leakage during storage is probably due, at least in part, to influx of electrolytes from cut (ruptured) cells into metabolically active (healthy) cells. Since electrolyte leakage is inversely related to tissue and membrane integrity (Marangoni et al., 1996; Murata 1989), reduced electrolyte leakage during storage may also indicate that a membrane damage recovery process is active during the early stages of storage following fresh-cut processing. In this study, the inverse relationship between delayed packaging time and electrolyte leakage may suggest that a 4- to 12-h exposure to ambient air $\left(21 \mathrm{kPa} \mathrm{O}_{2}\right)$ before packaging may increase the wound healing process and help to maintain tissue integrity during storage in low $\mathrm{O}_{2}$ and high $\mathrm{CO}_{2}$ atmospheres. Delays in packaging beyond the $12 \mathrm{~h}$ used in this study may further increase tissue recovery from wounding but also increases the risk of tissue dehydration and other oxidative stresses to cell membranes. When fresh-cut lettuce samples were placed in 8.0 or 16.6 OTR film packages and sealed with $1.5 \mathrm{kPa} \mathrm{O}_{2}$ or left unsealed, electrolyte leakage was lower in samples from unsealed packages during $6 \mathrm{~h}$ storage in humidified (>85\% RH) air at $5{ }^{\circ} \mathrm{C}$ (Fig. 5). However, storage

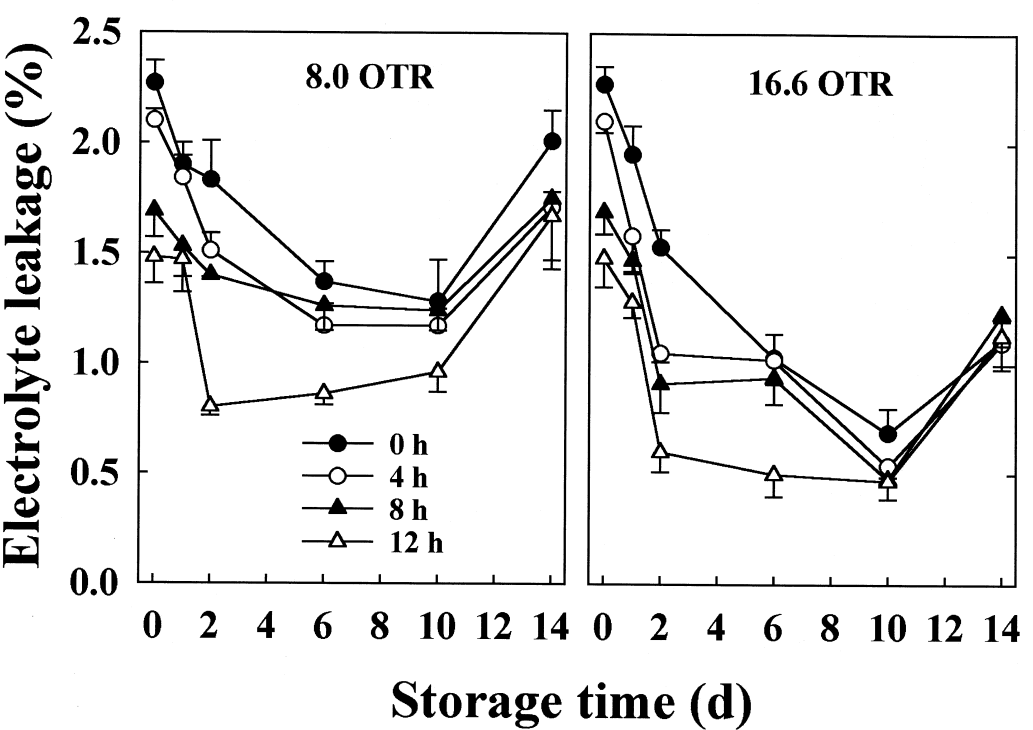

Fig. 4. Effect of delayed packaging treatments and packaging film oxygen transmission rate (OTR) on electrolyte leakage from fresh-cut romaine lettuce stored at $5{ }^{\circ} \mathrm{C}$ for up to $14 \mathrm{~d}$. Electrolyte leakage is expressed as a percentage of total electrolytes leaked from 50-g samples into 500-mL aliquots of distilled water at $5{ }^{\circ} \mathrm{C}$ following a 30 -min incubation period. The delay period between fresh-cut processing and packaging lettuce samples using 8.0 or $16.6 \mathrm{pmol} \cdot \mathrm{s}^{-1} \cdot \mathrm{m}^{-2} \cdot \mathrm{Pa}^{-1}$ OTR films was $0,4,8$, or $12 \mathrm{~h}$. Each symbol is the mean of three replicate measurements; vertical lines represent SE. SE bars were not shown when masked by the symbol.

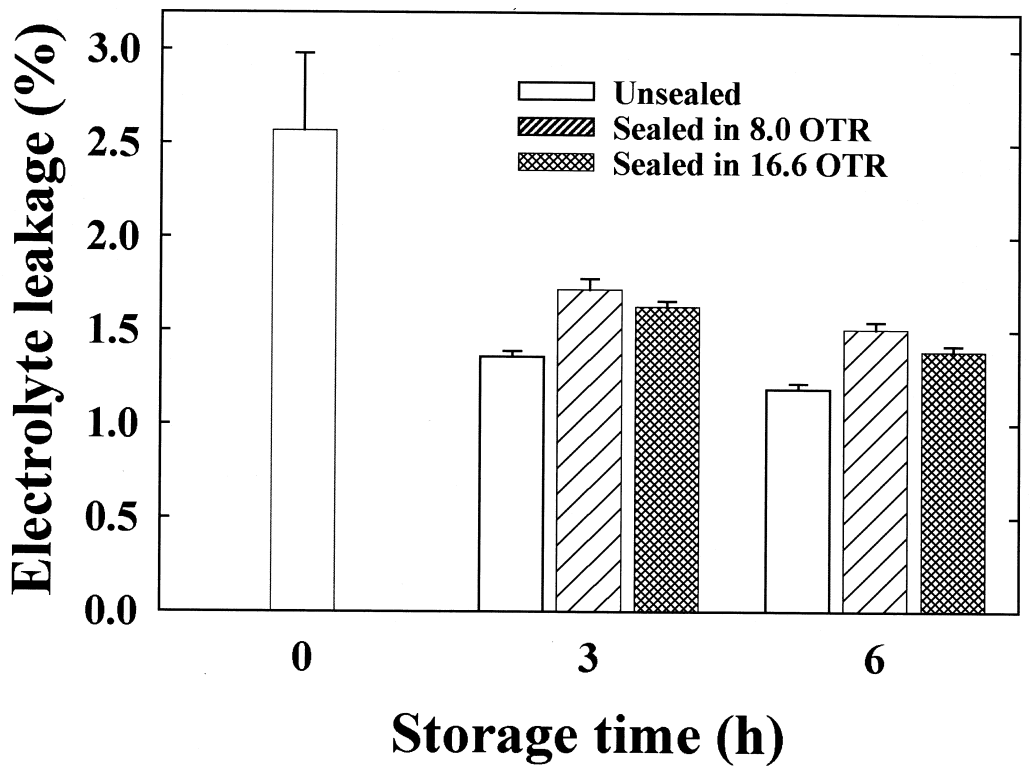

Fig. 5. Effect of unsealed and sealed 8.0 and $16.6 \mathrm{pmol} \cdot \mathrm{s}^{-1} \cdot \mathrm{m}^{-2} \cdot \mathrm{Pa}^{-1}$ oxygen transmission rate (OTR) film packages on electrolyte leakage from fresh-cut romaine lettuce stored at $5{ }^{\circ} \mathrm{C}$ for up to $6 \mathrm{~h}$. Electrolyte leakage is expressed as a percentage of total electrolytes leaked from $50 \mathrm{-g}$ samples into $500-\mathrm{mL}$ aliquots of distilled water at $5{ }^{\circ} \mathrm{C}$ following a 30 -min incubation period. Each histogram bar is the mean of three replicate measurements; vertical lines represent SE. in unsealed packages beyond $6 \mathrm{~h}$ resulted in greater electrolyte leakage than that from samples in sealed packages (data not shown). These results indicate that delays in packaging beyond 12 h may be even more beneficial than those reported in this study, but risks associated with tissue dehydration and other oxidative stresses are also increased.

VolATILE GASSES. The ethanol partial pressure increased inside packaged samples after day 2 (Fig. 6). There were interactions between storage time and film OTR $(P<0.0001)$, and between 
storage time and delayed packaging treatment $(P=$ 0.0037). For samples packaged with 8.0 OTR film, increased delay periods before packaging correspondingly decreased ethanol accumulation, though not significantly. Samples packaged immediately after processing accumulated ethanol more than two times faster than samples packaged with a 12-h delay. Among corresponding delayed packaging treatments, less ethanol accumulated in packages prepared from 16.6 OTR film than from 8.0 OTR film. For samples packaged with 16.6 OTR film, differences in ethanol accumulation among delayed packaging treatments were small and inconsequential. Acetaldehyde gas was first detected on day 6, and it accumulated as fast or faster in 8.0 than in 16.6 OTR film packages (Fig. 7). As with ethanol accumulation, acetaldehyde accumulation appeared to be transiently inhibited by delayed packaging.

Increased ethanol and acetaldehyde production is associated with anaerobic respiration, which occurs in low $\mathrm{O}_{2}$ and high $\mathrm{CO}_{2}$ atmospheres. As reported by Smyth et al. (1998), a MA of $2 \mathrm{kPa} \mathrm{O}_{2}$ and $10 \mathrm{kPa} \mathrm{CO}_{2}$ increased ethanol and acetaldehyde production in lettuce. Lopez-Galvez et al. (1997) reported that ethanol partial pressures of commercial fresh-cut products were 1.2 to $2.0 \mathrm{kPa}$ after 10 to $15 \mathrm{~d}$ at $5{ }^{\circ} \mathrm{C}$, which is similar to the ethanol partial pressure of samples packaged with 8.0 OTR film and higher than those from samples packaged with 16.6 OTR film. While a very low $(\approx 1 \mathrm{~Pa})$ partial pressure of ethanol and acetaldehyde may have a floral-fruity or otherwise pleasant odor (R. Saftner, personal observation), higher partial pressures can have a pungent, ethereal odor (SigmaAldrich Chemical Co., 2003), bitter taste (Windholz, 1976) or otherwise adulterate aromatic volatile profiles of lettuce and contribute to off-odor development. Variations in fermentative volatile production among delayed packaging treatments may have been due to the different rates of $\mathrm{O}_{2}$ depletion (Fig. 2) and/or $\mathrm{CO}_{2}$ accumulation (Fig. 3) inside the packages. However, the lower electrolyte leakage (Fig. 4) observed in the delayed packaging treatments may also suggest a wound healing process that renders lettuce tissue to be more resistant to low $\mathrm{O}_{2} /$ high $\mathrm{CO}_{2}$ atmospheres and associated fermentative volatile production.

OFF-ODOR DEVELOPMENT. Off-odor was affected by storage time, film OTR and delayed packaging treatment (Fig. 8). Off-odor was first detected on days 2 and 6 in samples processed without delayed packaging in 8.0 and 16.6 OTR film packages, respectively. Delayed packaging delayed by up to $4 \mathrm{~d}$ the onset of off-odor development in both film packages. Compared to packaging without delay, the 8 - and 12 -h delayed packaging treatments generally inhibited the intensity of off-odors. The pattern of off-odor development was similar to the pattern of ethanol and acetaldehyde accumulation among corresponding film and delayed packaging treatments (Figs. 6-8). Lopez-Galvez et al. (1997) previously reported a correlation between off-odor development in packaged lettuce tissues and ethanol and acetaldehyde partial pressures in the packages. Off-odor development in lettuce is often a consequence of anaerobic respiration that occurs in low $\mathrm{O}_{2}$ and elevated $\mathrm{CO}_{2}$ atmospheres (Cameron et al., 1995; Smyth

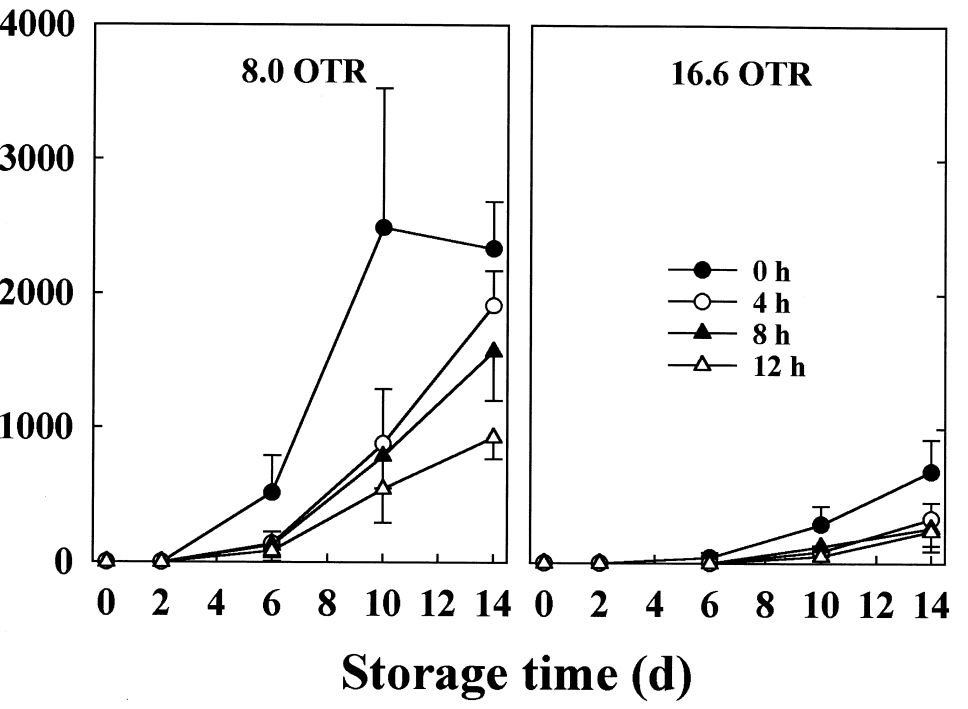

g. Effect of delayed packaging treatments and packaging film oxygen transmission rate (OTR) on ethanol partial pressure within packages of fresh-cut romaine lettuce packaged with $1.5 \mathrm{kPa} \mathrm{O}_{2}$ and stored at $5{ }^{\circ} \mathrm{C}$ for up to $14 \mathrm{~d}$. The delay period between fresh-cut processing and packaging lettuce samples using 8.0 or $16.6 \mathrm{pmol} \cdot \mathrm{s}^{-1} \cdot \mathrm{m}^{-2} \cdot \mathrm{Pa}^{-1} \mathrm{OTR}$ films was $0,4,8$, or $12 \mathrm{~h}$. Each symbol is the mean of three replicate measurements; vertical lines represent SE. SE bars were not shown when masked by the symbol.

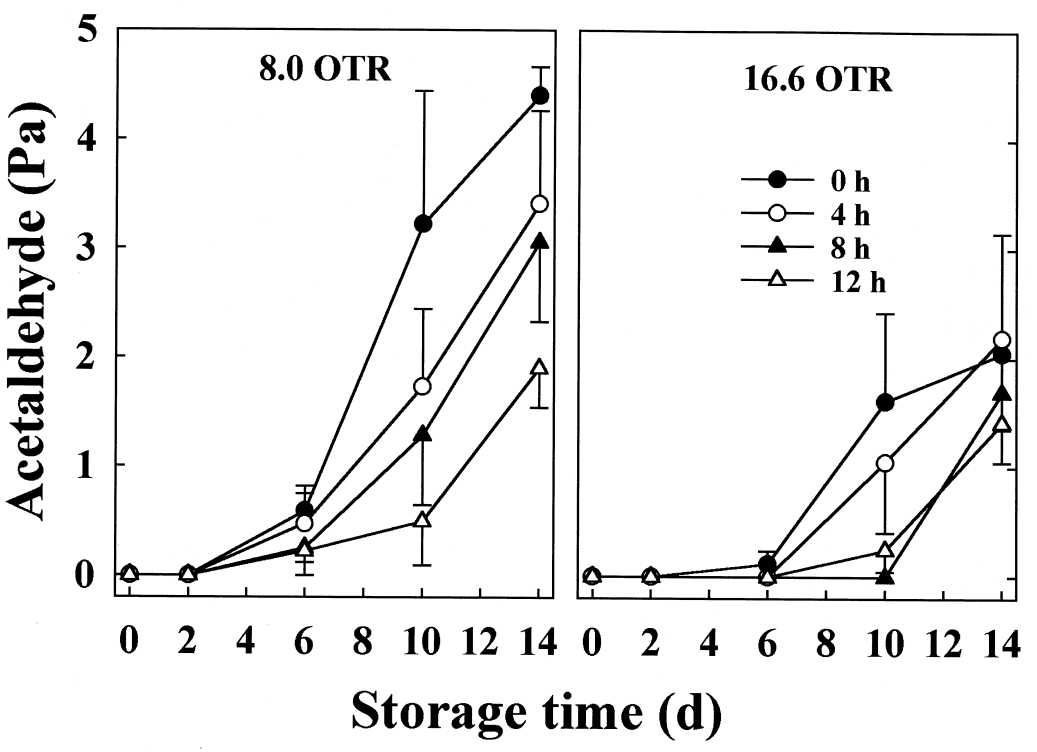

ig. 7. Effect of delayed packaging treatments and packaging film oxygen transmission rate (OTR) on acetaldehyde gas partial pressure within packages of fresh-cut romaine lettuce packaged with $1.5 \mathrm{kPa} \mathrm{O}_{2}$ and stored at $5^{\circ} \mathrm{C}$ for up to $14 \mathrm{~d}$. The delay period between freshcut processing and packaging lettuce samples using 8.0 or $16.6 \mathrm{pmol} \cdot \mathrm{s}^{-1} \cdot \mathrm{m}^{-2} \cdot \mathrm{Pa}^{-1} \mathrm{OTR}$ films was $0,4,8$, or $12 \mathrm{~h}$. Each symbol is the mean of three replicate measurements; vertical lines was $0,4,8$, or $12 \mathrm{~h}$. Each symbol is the mean of three replicate meast
represent SE. SE bars were not shown when masked by the symbol.

et al., 1998). In the present study, delayed packaging treatments effectively delayed the onset and decreased the intensity of offodors probably by reducing anaerobic respiration and ethanol and acetaldehyde accumulation at least under lower than optimal film OTR packaging conditions.

Discoloration AND $\mathrm{CO}_{2}$ INJURY. Discoloration appeared first on the cut end of vascular bundles as oval pinkish lesions that later developed into brown patches along the entire length of the cut edges of the packaged lettuce slices. For samples in 8.0 OTR film packages, the 0-, 4-, and 8-h delayed packaging 
treatments prevented discoloration and there was only a slight discoloration on samples packaged after a 12-h delay (Table 1). With 16.6 OTR film packaging, discoloration was more intense and started earlier than in corresponding samples packaged with 8.0 OTR film. There also was a more pronounced effect of the delay period before packaging on discoloration in 16.6 than in 8.0 OTR film packages. Cut-edge browning is a result of the oxidation of phenolic compounds catalyzed by polyphenol oxidase in the presence of $\mathrm{O}_{2}$. Lopez-Galvez et al. (1996a, 1996b) reported that browning in lettuce is closely related to the $\mathrm{O}_{2}$ partial pressures in the packages, and Smyth et al. (1998) showed that browning is not affected by the presence or absence of $\mathrm{CO}_{2}$. The higher intensity of discoloration in 16.6 vs. 8.0 OTR film packaged samples is probably due to the higher $\mathrm{O}_{2}$ partial pressures (Fig. 2) in those packages. Delayed packaging, which prolonged exposure to $21 \mathrm{kPa} \mathrm{O}_{2}$, increased discoloration. This suggests that delayed packaging should be avoided whenever the film OTR is higher than optimal for the lettuce being packaged. In contrast, when film OTR is less than optimal for packaging fresh-cut lettuce, delayed packaging treatments had little to no impact on discoloration (Table 1) since browning was effectively controlled by the essentially $\mathrm{O}_{2}$-depleted atmospheres in 8.0 OTR film packages (Fig. 2).

Except for 12-h delayed packaging into 16.6 OTR film packages, $\mathrm{CO}_{2}$ injury was first detected at day 6 (Table 2). The first symptom of $\mathrm{CO}_{2}$ injury is the development of a brown stain on the midrib surfaces caused by variable-sized sunken or yellowish lesions that later became more delineated and darker in appearance (Lopez-Galvez et al., 1996b). In this study, $\mathrm{CO}_{2}$ injury was primarily noted on the midrib surfaces of the outer leaves and immature inner leaves of romaine lettuce. $\mathrm{CO}_{2}$-associated injury (Table 2) and $\mathrm{CO}_{2}$ partial pressure (Fig. 3) were similarly higher in correspondingly treated samples packaged with 8.0 vs. 16.6 OTR film. Cameron et al. (1995) and Lipton (1987) have reported

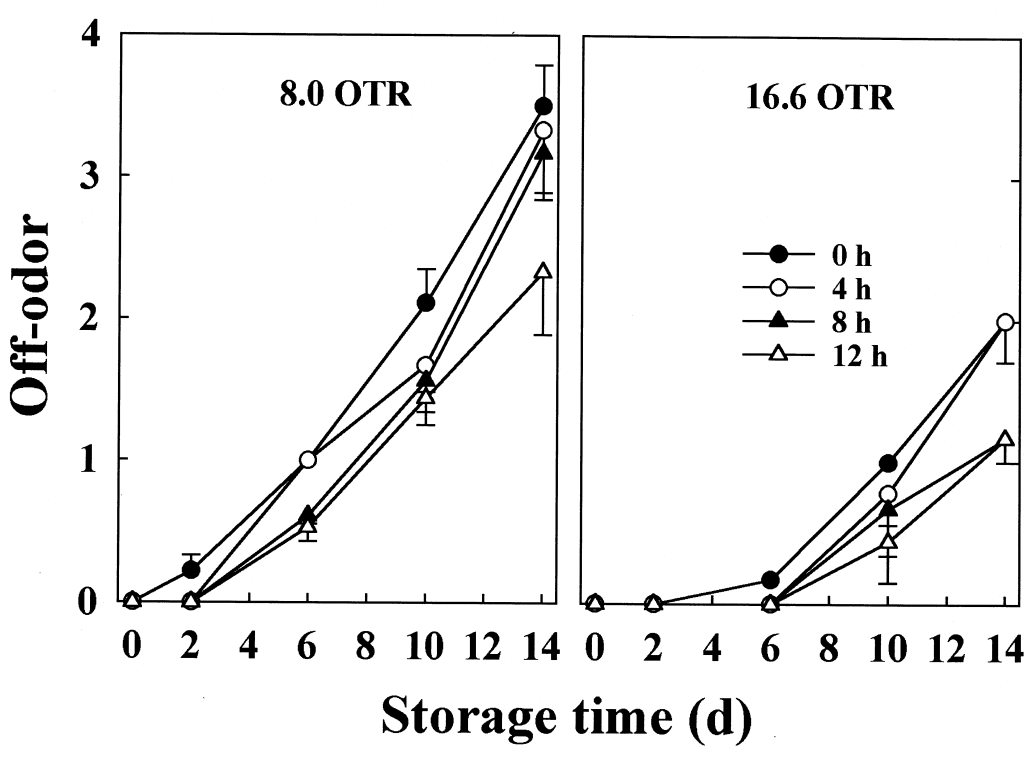

Fig. 8. Effect of delayed packaging treatments and packaging film oxygen transmission rate (OTR) on off-odor development within packages of fresh-cut romaine lettuce packaged with $1.5 \mathrm{kPa} \mathrm{O}_{2}$ and stored at $5^{\circ} \mathrm{C}$ for up to $14 \mathrm{~d}$. The delay period between fresh-cut processing and packaging lettuce samples using 8.0 or $16.6 \mathrm{pmol} \cdot \mathrm{s}^{-1} \cdot \mathrm{m}^{-2} \cdot \mathrm{Pa}^{-1} \mathrm{OTR}$ films was $0,4,8$, or $12 \mathrm{~h}$. Off-odor was scored by three trained panelists using a 0 to 4 hedonic scale where $0=$ none; 1 = slight; 2 = moderate; $3=$ strong; and $4=$ severe. Each symbol is the mean of three measurements performed by three trained panelists on each of three replicate samples $(n=9)$; vertical lines represent SE. SE bars were not shown when masked by the symbol.

that 5 to $15 \mathrm{kPa} \mathrm{CO}_{2}$ could cause the development of brown stain in romaine lettuce as the consequence of $\mathrm{CO}_{2}$ injury. With 8.0 OTR film, delayed packaging treatments effectively inhibited the development of $\mathrm{CO}_{2}$ injury. The 12-h delayed packaging treatment inhibited the development of $\mathrm{CO}_{2}$ injury by $\approx 50 \%$ compared to the nondelayed packaging treatment. Besides decreasing the $\mathrm{CO}_{2}$ partial pressure in packaged samples, delayed packaging treatments may also have reduced the susceptibility of lettuce to $\mathrm{CO}_{2}$ injury as suggested by the delayed packaging-induced decreases in tissue electrolyte leakage (Fig. 4). This underscores the need

Table 1. Effect of delayed packaging treatments on discoloration index score of fresh-cut romaine lettuce stored for up to $14 \mathrm{~d}$ at $5{ }^{\circ} \mathrm{C}$.

\begin{tabular}{|c|c|c|c|c|c|c|c|c|}
\hline \multirow{3}{*}{$\begin{array}{l}\text { Delayed } \\
\text { packaging } \\
\text { treatment } \\
\text { (h) }\end{array}$} & \multicolumn{8}{|c|}{ Discoloration index score ${ }^{z}$} \\
\hline & \multicolumn{4}{|c|}{$\begin{array}{c}\text { Storage time in } 8.0 \text { OTR }^{y} \\
\text { packages }(\mathrm{d})\end{array}$} & \multicolumn{4}{|c|}{$\begin{array}{c}\text { Storage time in 16.6 OTR } \\
\text { packages }(\mathrm{d})\end{array}$} \\
\hline & 2 & 6 & 10 & 14 & 2 & 6 & 10 & 14 \\
\hline 0 & 0 & 0 & 0 & 0 & 0 & 0 & $0.3 \mathrm{c}^{\mathrm{w}} \mathrm{B}^{\mathrm{v}}$ & $1.5 \mathrm{~b} \mathrm{~A}$ \\
\hline 4 & 0 & 0 & 0 & 0 & 0 & 0 & 0.4 c B & $1.7 \mathrm{~b} \mathrm{~A}$ \\
\hline 8 & 0 & 0 & 0 & 0 & 0 & $0.3 \mathrm{c} \mathrm{A}$ & $1.6 \mathrm{~b} \mathrm{~A}$ & $1.7 \mathrm{~b} \mathrm{~A}$ \\
\hline 12 & 0 & $0.2 \mathrm{c} \mathrm{B}$ & $0.2 \mathrm{c} \mathrm{B}$ & $0.3 \mathrm{c} \mathrm{B}$ & 0 & $0.8 \mathrm{c} \mathrm{A}$ & $2.6 \mathrm{a} \mathrm{A}$ & $2.8 \mathrm{a} \mathrm{A}$ \\
\hline
\end{tabular}

${ }_{2}$ Discoloration was evaluated using a five-point scoring system but pieces with discoloration were sorted into groups based on the degree of discoloration where $0=$ none; $1=$ beginning of discoloration as oval pinkish lesions at the edge of the midrib; $2=$ moderate browning on both sides of midrib; $3=$ strong browning along the midrib; and $4=$ severe browning along the midrib. Results are expressed as an index score calculated by taking the sum of each score multiplied by the corresponding number of pieces in three replicate 170-g samples having that score, dividing by the total number of lettuce pieces evaluated, and then multiplying by 100 .

yOTR $=$ oxygen transmission rate.

xTime period at $5{ }^{\circ} \mathrm{C}$ from fresh-cut processing to packaging.

wTreatment means within Time (columns) with different $\mathrm{a}, \mathrm{b}, \mathrm{c}$ letters are different at $\alpha=0.05$ using Sidak-adjusted $P$ values.

vTime means within Treatment (rows) with different A, B letters are different at $\alpha=0.05$ using Sidakadjusted $P$ values. 
Table 2. Effect of delayed packaging on carbon dioxide injury index score of fresh-cut romaine lettuce stored for up to $14 \mathrm{~d}$ at $5{ }^{\circ} \mathrm{C}$.

\begin{tabular}{|c|c|c|c|c|c|c|c|c|}
\hline \multirow{3}{*}{$\begin{array}{l}\text { Delayed } \\
\text { packaging } \\
\text { treatment }^{x} \\
\text { (h) }\end{array}$} & \multicolumn{8}{|c|}{$\mathrm{CO}_{2}$ injury index score ${ }^{z}$} \\
\hline & \multicolumn{4}{|c|}{$\begin{array}{l}\text { Storage time in } 8.0 \mathrm{OTR}^{\mathrm{y}} \\
\text { packages }(\mathrm{d})\end{array}$} & \multicolumn{4}{|c|}{$\begin{array}{c}\text { Storage time in 16.6 OTR } \\
\text { packages (d) }\end{array}$} \\
\hline & 2 & 6 & 10 & 14 & 2 & 6 & 10 & 14 \\
\hline 0 & 0 & $2.9 \mathrm{a}^{\mathrm{w}} \mathrm{C}^{\mathrm{v}}$ & $6.4 \mathrm{a} B$ & $12.6 \mathrm{a} \mathrm{A}$ & 0 & $2.0 \mathrm{ab} \mathrm{C}$ & $3.1 \mathrm{bc} \mathrm{C}$ & $6.6 \mathrm{~b} \mathrm{~B}$ \\
\hline 4 & 0 & $2.2 \mathrm{ab} C D$ & $6.3 \mathrm{a} \mathrm{B}$ & $11.6 \mathrm{a} A$ & 0 & $1.3 \mathrm{bc} \mathrm{D}$ & $2.4 \mathrm{~cd} \mathrm{CD}$ & $4.0 \mathrm{c} \mathrm{C}$ \\
\hline 8 & 0 & $1.6 \mathrm{bc} \mathrm{DE}$ & $6.2 \mathrm{a} \mathrm{B}$ & $11.4 \mathrm{a} \mathrm{A}$ & 0 & $0.2 \mathrm{~d} E$ & 1.8 de $\mathrm{D}$ & $2.7 \mathrm{c} \mathrm{C}$ \\
\hline 12 & 0 & $0.9 \mathrm{~cd} \mathrm{C}$ & $3.2 \mathrm{~b} \mathrm{~B}$ & $6.5 \mathrm{~b} \mathrm{~A}$ & 0 & 0 & $1.4 \mathrm{e} \mathrm{BC}$ & $2.0 \mathrm{c} \mathrm{BC}$ \\
\hline
\end{tabular}

${ }^{2} \mathrm{CO}_{2}$ injury was scored on a five-point scale based on the degree of brown staining of the fresh-cut lettuce where $0=$ none; $1=$ beginning of injury; $2=<1 / 4$ surface area injured; $3=$ between $1 / 4$ to $1 / 2$ surface area injured; and $4=>1 / 2$ surface area injured. Results are expressed as an index score that was calculated as described above for discoloration index score.

yOTR $=$ oxygen transmission rate.

xTime period at $5{ }^{\circ} \mathrm{C}$ from fresh-cut processing to packaging.

wTreatment means within Time (columns) with different $\mathrm{a}, \mathrm{b}, \mathrm{c}, \mathrm{d}$, e letters are different at $\alpha=0.05$ using Sidak-adjusted $P$ values.

vTime means within Treatment (rows) with different A, B, C, D, E letters are different at $\alpha=0.05$ using Sidak-adjusted $P$ values.

for more detailed research on oxidative and $\mathrm{CO}_{2}$-induced stresses in delayed packaging and MAP systems.

Overall Quality. Overall quality at the end of storage is a factor of film OTR and the delay period before packaging, and there was an interaction between film OTR and packaging delay periods (Fig. 9). Samples packaged with 8.0 OTR film generally had a lower overall quality score than the corresponding samples in 16.6 OTR film packaging. This was primarily due to the relatively high levels of $\mathrm{CO}_{2}$ injury (Table 1) and off-odor development (Fig. 8) that occurred in 8.0 OTR film packaging regardless of delayed packaging treatments. However, a 12-h delayed packaging treatment did maintain quality reasonably well and better than other delayed packaging treatments in 8.0 OTR film packages. In contrast, the 12-h delayed packaging treatment reduced overall quality in 16.6 OTR-packaged samples by increasing cut-edge discoloration (Table 1). An 8-h delayed packaging treatment

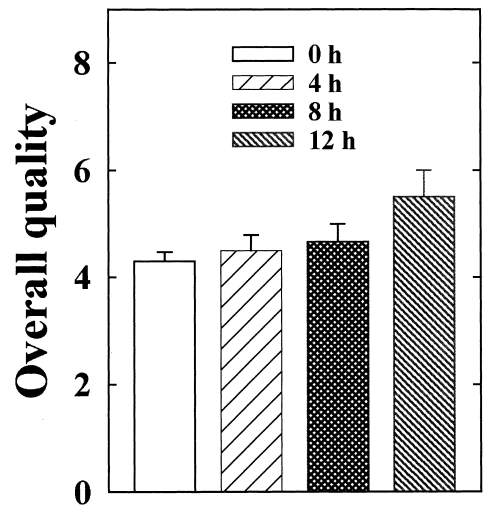

8.0 OTR

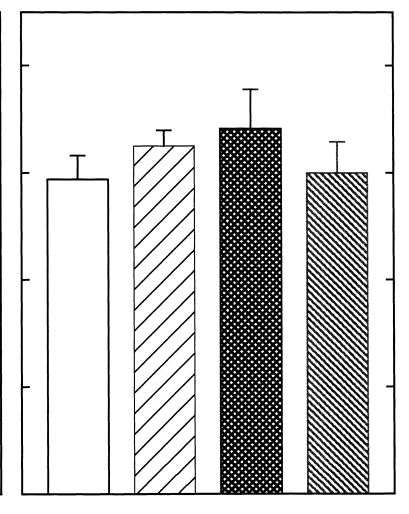

16.6 OTR
Fig. 9. Effect of delayed packaging treatments and packaging film oxygen transmission rate (OTR) on overall quality of fresh-cut romaine lettuce packaged with $1.5 \mathrm{kPa} \mathrm{O}_{2}$ and stored at $5{ }^{\circ} \mathrm{C}$ for up to $14 \mathrm{~d}$. The delay period between fresh-cut processing and packaging lettuce samples using 8.0 or 16.6 $\mathrm{pmol} \cdot \mathrm{s}^{-1} \cdot \mathrm{m}^{-2} \cdot \mathrm{Pa}^{-1}$ OTR films was $0,4,8$, or $12 \mathrm{~h}$. Overall quality was scored by three trained panelists using a 1 to 9 hedonic scale where $1=$ dislike extremely; $2=$ dislike very much; 3 = dislike moderately; $4=$ dislike slightly; 5 = neither like nor dislike; $6=$ like slightly; $7=$ like moderately; $8=$ like very much; and $9=$ like extremely. Each symbol is the mean of three measurements performed by three trained panelists on each of three replicate samples $(n=9)$; vertical lines represent SE. in 16.6 OTR film packaging maintained the overall quality of romaine lettuce by minimizing $\mathrm{CO}_{2}$ injury without increasing discoloration to an unacceptable level.

\section{Conclusions}

Packaging film OTRs of 8.0 and 16.6 and delayed packaging treatments up to $12 \mathrm{~h}$ affected package atmospheres and consequently affected the quality of fresh-cut romaine lettuce. There was a significant interaction between film OTR and the delay period before packaging on product quality. When the lower than optimal 8.0 OTR film was used for packaging lettuce, package atmospheres were low in $\mathrm{O}_{2}$ and high in $\mathrm{CO}_{2}$, resulting in strong off-odor and accumulation of ethanol and acetaldehyde. Delayed packaging into 8.0 OTR film packages was beneficial by reducing ethanol and acetaldehyde production, delaying off-odor development and alleviating $\mathrm{CO}_{2}$ injury. When the higher than optimal 16.6 OTR film was used for packaging fresh-cut lettuce, delayed packaging treatments up to $12 \mathrm{~h}$ increased cut-edge discoloration but otherwise was beneficial in maintaining good quality during $14 \mathrm{~d}$ storage at $5{ }^{\circ} \mathrm{C}$. Overall, the results indicated that the impact of delayed packaging on product quality depended on the atmosphere within the packages. When $\mathrm{O}_{2}$ level in the packages was lower than optimal and $\mathrm{CO}_{2}$ was higher than optimal, delayed packaging up to $12 \mathrm{~h}$ was beneficial to maintaining quality by reducing ethanol and acetaldehyde production and delaying the development of off-odor and alleviating $\mathrm{CO}_{2}$ injury. On the contrary, when the $\mathrm{O}_{2}$ partial pressure in the packages was higher than optimal and the product showed signs of discoloration, delayed packaging can be detrimental to product quality by aggravating discoloration.

\section{Literature Cited}

Abeles, F.B., P.W. Morgan, and M.E. Saltveit. 1992. Ethylene in plant biology. 2nd ed. Academic, San Diego.

ASTM International. 1986. Oxygen gas transmission rate through plastic film and sheeting using a coulometric sensor. Annu. Book of ASTM Standards 8:387-393.

Brecht, J.K. 1995. Physiology of lightly processed fruits and vegetables. HortScience 30:18-22.

Cameron, A.C., P.C. Talasila, and D.W. Joles. 1995. Predicting film permeability needs for modified atmosphere packaging of lightly processed fruits and vegetables. HortScience 30:25-34. 
Cornforth, I.S. 1975. The persistence of ethylene in aerobic soil. Plant Soil 42:85-96.

Hong, J.H. and K.C. Gross. 1998. Surface sterilization of whole tomato fruit with sodium hypochlorite influence subsequent postharvest behavior of fresh-cut slices. Postharvest Biol. Technol. 13:51-58.

Hong, J.H., J.M. Douglas, J.C. Mary, and K.C. Gross. 2000. Tomato cultivation systems affect subsequent quality of fresh-cut fruit slices. J. Amer. Soc. Hort. Sci. 125:729-735.

Huxsoll, C., H. Bolin, and A. King, Jr. 1989. Physiochemical changes and treatments for lightly processed fruits and vegetables, p. 203-215. In: J.J. Jenn (ed.). Quality factors of fruits and vegetables - Chemistry and technology. Amer. Chem. Soc., Washington, D.C.

Jackson, M.B., T.M. Fenning, M.C. Drew, and L.R. Saker. 1985. Stimulation of ethylene production and gas-space (aerenchyma) formation in adventitious roots of Zea mays L. by small partial pressures of oxygen. Planta 165:486-492.

Jacxsens, L., F. Devlieghere, and J. Debevere. 2002. Predictive modelling for packaging design: equilibrium modified atmosphere packages of fresh-cut vegetables subjected to a simulated distribution chain. Intl. J. Food Microbiol. 73:331-341.

Jiang, Y., T. Shina, N. Nakamura, and A. Nakahara. 2001. Electrical conductivity evaluation of postharvest strawberry damage. J. Food Sci. 66:1392-1395.

Kim, J.G., Y. Luo, and K.C. Gross. 2004. Effect of package film on the quality of fresh-cut salad savoy. Postharvest Biol. Technol. 32:99-107.

Lakakul, R., R.M. Beaudry, and R.J. Hernandez. 1999. Modeling respiration of apple slice in modified atmosphere packages, J. Food Sci 64:105-110.

Lipton, W.J. 1987. Carbon dioxide-induced injury of romaine lettuce stored in controlled atmospheres. HortScience 22:461-463.

Loaiza, J. and M. Cantwell. 1997. Postharvest physiology and quality of cilantro (Coriandrum sativum L.). HortScience 32:104-107.
Lopez-Galvez, G., M. Saltveit., and M. Cantwell. 1996a. The visual quality of minimally processed lettuces stored in air or controlled atmosphere with emphasis on romaine and iceberg types. Postharvest Biol. Technol. 8:179-190.

Lopez-Galvez, G., M. Saltveit, and M. Cantwell. 1996b. Wound-induced phenylalanine ammonia lyase activity: factors affecting its induction and correlation with the quality of minimally processed lettuces. Postharvest Biol. Technol. 9:223-233.

Lopez-Galvez, G., G. Peiser, X. Nie, and M. Cantwell. 1997. Quality changes in packaged salad products during storage. Zeithschrift Lebensmittel-Untersuchung Forschung. 205:64-72.

Luo, Y., J.L. McEvoy, M.R. Wachtel, J.G. Kim, and Y. Huang. 2004. Package atmosphere affects postharvest biology and quality of freshcut cilantro leaves. HortScience 39:567-570.

Marangoni, A.G., T. Palma, and D.W. Stanley. 1996. Membrane effects in postharvest physiology. Postharvest Biol. Technol. 7:193-217.

Meilgaard, M., G.V. Civille, and B.T. Carr. 1991. Sensory evaluation techniques. 2nd ed. CRC Press, Boca Raton, Fla.

Moyls, L., R. Hocking, T. Beveridge, and G. Timbers. 1992. Exponential decay method for determining gas transmission rate of films. Trans. ASAE 35:1259-1265.

Murata, T. 1989. Relation of chilling stress to membrane permeability, p. 201-209. In: C.Y. Wang (ed.). Chilling injury of horticultural crops. CRC Press, Boca Raton, Fla.

SAS Institute. 1999. SAS/STAT user's guide, version 8. SAS Inst., Cary, N.C.

Sigma-Aldrich Chemical Company. 2003. Flavors and fragrances. Sigma-Aldrich Chem. Co., Milwaukee, Wis.

Smyth, A.B., J. Song, and A.C. Cameron. 1998. Modified atmosphere packaged cut iceberg lettuce: Effect of temperature and $\mathrm{O}_{2}$ partial pressure on respiration and quality. J. Agr. Food Chem. 46:4556-4562.

Windholz, M. (ed.). 1976. The Merck Index. 9th ed. Merck \& Co., Rahway, N.J. 